\title{
On the structure of the mucilage-secreting cells of Blechnum occidentale, L., and Osmunda regalis, $\mathrm{L}$.
}

BY

WALTER GARDINER, M.A.

AND

TOKUTARO ITO, F.L.S.

With Plates III and IV.

\section{INTRODUCTORY AND HISTORICAL ${ }^{1}$.}

$\mathrm{N}$ ascending the Vegetable Kingdom it is among the Ferns

that we first meet with any great variety in the forms of the hairs which occur on the young, or the adult, stem and leaf. At this point, however, associated with a rapidly increasing complexity of the aerial members, we find trichomes of the most diverse structure and function which may even rank with those of the highest of the Dicotyledons, and among the most interesting are the hairs which are endowed with the power of secretion, and thus contribute in an especially marked manner to some physiological necessity of the plant upon which they are borne.

Such hairs have been long known. From the point of view of their secretion they may conveniently be divided into two classes, namely those secreting mucilage and those secreting

1 In the case of composite papers it is not uncommon to attach all the credit to the pergon whose name appears firgt upon the title-page. I wish distinctly to state that it must not be so in the present instance. The work was certainly suggested by myself and carried out under my direction, but we have each of as done our own share in the investigation and worked in common throngh all the results. To Mr. Ito indeed fell the task, not only of making observations, but also of drawing the whole of the figares, and their wonderful and appreciative realism will sufficiently prove his capabilities more than any remarks of mine can do. For writing the paper I am myself responsible.-WALTER GARDINER.

[ Annals of Botany, Vol. I. No. I. August I887.] 
resin. The capitate mucilage-secreting hairs, which have been since shown to occur very commonly on the young stems, leaves and paleae of so many ferns, were first figured in the case of Polypodium aureum, L., by Suminski ${ }^{1}$ in his excellent and well-known drawings of young germinating plants. Hofmeister ${ }^{2}$ represents similar hairs of $P$ teris aquilina, L., and those of the young scale (palea) of Polypodium serpens, Forst, and $\mathrm{Kny}^{3}$, in the case of Ceratopteris thalictroides, Brongn., figures the various stages in a developing scale in all of which the terminal mucilage-secreting hair is well shown. Hitherto but little notice had been taken of the more minute histology of the structures; and it was Prantl ${ }^{4}$, and after him Sadebeck ${ }^{5}$, who described the mucilaginous character of the cell-contents. In the case of Osmunda regalis, $\mathrm{L}$., de Bary ${ }^{6}$ drew attention to the long septate mucilage-secreting hairs; and quite recently Goebeler', in his paper 'Die Schutzvorrichtungen am Stammscheitel der Farne,' gives by far the most complete account extant, not only of the general distribution of secretory and protective hairs throughout the Filicineae, but also of their histology and physiological significance.

We may now pass on to the literature of the resin-secreting glands, and here the unique intercellular hairs of Aspidium Filix-mas, Sw., claim the first place. These occur in the intercellular spaces of the rhizome and the base of the petiole, and as $\mathrm{Sachs}^{8}$ afterwards showed in a similar position in the leaf-parenchyma. They were observed by Mettenius ${ }^{0}$, but to

\footnotetext{
1 Suminski, Zar Entwicklangsgeschichte des Farnkraüter, $18_{4} 8$.

'Hofmeister, Vergleichende Untersachangen, Leipzig, 1851, and in Abh. d. König. Säch. Ges. d. Wiss., 1857 .

Kny, Entwick. d. Parkeriaceen, 1875.

- Prantl, Morphologie d. Gefasskryptogamen, I881.

- Sadebeck, in Verhandlung d. bot. Ver. d. prov. Brandenbarg, 1884. He figures young mucilage glands of $A$ splenium Serpentini.

- De Bary, Comparative Anatomy of Phanerogams and Ferns, p. 99. The harrs were first described by Milde, Monogr. generis Osmundæ, Vindob. 1868.

' Gœebeler in Flora, 1886.

- Sachs, Textbook of Botany, and ed. p. 439. Sachs also figures the mucilageglands of the sporangia of Aspudium Filix-mas.

- Mettening, Filices horti Lipsiensis, Leiprig, $185^{6}$.
} 
Schacht ${ }^{1}$ belongs the credit of bringing these remarkable structures more prominently into view by describing and figuring them in his paper in Pringsheim's Jahrbuch. Besides the intercellular hairs other resin-secreting trichomes of similar structure occur on the paleae of various species of Aspidium. Thus de Bary ${ }^{2}$ mentions Aspidium Filix-mas, Sw., Aspidium spinulosum, Sw., and Aspidium molle, Sw., as possessing capitate glandular hairs, and Goebeler ${ }^{3}$ shows that in Aspiditım Sieboldi, Van Houtt, like glands occur. We may also add to the list Bleclinum occidentale, which bears resin-glands both on the paleae and the young leaves. Any account of the secreting hairs of ferns would obviously be incomplete did we not allude to the resin-glands which characterise such ferns as the species of Gymnogramme. They are of course quite homologous to those already described, except that the secretion appears in the form of numerous rods which stand out on all sides upon the surface of the secreting cell. The substance secreted appears to be partly resinous and partly waxy in character. They are fully described by de Bary ${ }^{4}$ who gives the literature connected with them, and Goebeler also briefly alludes to them in the exhaustive paper to which we have already referred. Hairs of the Gymnogramme-type, producing their dustylooking secretion in the form of resin-rods, persist even on the adult leaves, but the glandular hairs which we now describe are associated distinctly with bud-formations ; they are therefore transitory in character. Whether on the leaves or paleae, they can only be observed in the youngest members, and here their secretory character is very marked, the whole apical portion of the young shoot being usually bathed with the mucilage derived from them. The hairs are very simple in structure, consisting either of a filament of cells all of which secrete (Osmunda), or occurring as stalked capitate hairs (Blechnum) when only the end cell is glandular. In the same individual both resinous and mucilaginous hairs may occur, but the first development of the two forms is quite similar,

${ }^{1}$ Schacht in Pringsheim's Jahrb., Bd. III.

'Goebeler, loc. cit.
${ }^{2}$ De Rary, loc. cit., p. 89.

' De Bary, loc. cit., p. 99. 
and the most important difference between them consists in the kind and manner of secretion. The physiological function of these glandular structures has already been sufficiently treated by Goebeler. One would here briefly point out that the mucilage and resin serve a most important purpose in the plant-economy, particularly by preventing too excessive transpiration in the young and delicate buds, and by serving as a reservoir for water against times of drought. Similarly the woolly hairs protect the plant both from injury from without and from the dangerous effects of extreme variations of temperature.

In the present paper we attempt to give a more detailed account than has hitherto appeared of the minute histology of two forms of mucilage-secreting hairs, viz. those of Blechnum occidentale, L., and Osmunda regalis, L., and we also endeavour to describe the various phenomena which are associated with mucilaginous secretion. This work was suggested partly by Prof. de Bary's remarks upon the mucilagehairs of Osmunda regalis, L.1, and partly by an observation made by the first-mentioned of the present authors, that in Blechnum brasiliense, Desv., there were mucilaginous hairs associated with the young bud.

\section{METHOD OF RESEARCH.}

The observation of the secretory structures of which we write presents but little difficulty. All but the very youngest leaves having been removed from the fern-shoot under examination, the developing paleae or the developing leaves are separated as required, and then further dissected and teased out under a low power of the dissecting microscope. By this means hairs of all ages may easily be obtained.

Fresh material gives by far the most satisfactory results. Alcohol causes abnormal shrinking of the mucilage attended by great distortion of structure. Saturated watery picric acid on the other hand produces great swelling of the mucilaginous contents, which finally ends in the rupture of the cell and the

\footnotetext{
${ }^{1}$ De Bary, loc. cit., p. 99.
} 
escape of the mucilage contained in them. Chromic acid is more satisfactory. A solution of $1^{\prime} 5$ to 2.0 per cent. strength was employed and the tissue was exposed to its action for twenty-four hours and was then freely washed in water. By the use of so strong a solution the voluminous tannin-precipitate which first appears is subsequently dissolved in the excess of the reagent, and after washing the cell appears clear and the tannin has been removed ${ }^{1}$. The observation of fresh material mounted in iodine or in 5 to I per cent. of osmic acid gives excellent results ${ }^{2}$. With iodine the deeply stained brown protoplasm and nucleus are sharply contrasted with the clear yellow mucilage, and with osmic acid the mucilage-drops which contain tannin stand out dark and well defined, while the ectoplasm and the endoplasmic framework remain hyaline and brilliant with just the faintest yellow coloration. With both these reagents the cell-contents are exceedingly well preserved.

Picronigrocin (24 hours) was also employed with success, and such material, after washing in water and mounting in glycerine, furnished quite the most satisfactory permanent preparations. As staining reagents, iodine, osmic acid, Hanstein's violet-fuchsin, haematoxylin, methylene-blue, Hofmann's blue, and eosin were chiefly used. Both Hanstein's violet-fuchsin and eosin were especially valuable, not only on account of their staining properties, but also for the comparative rapidity with which they diffused into the cell contents; with these exceptions, the aniline dyes penetrated the mucilage with great difficulty, and long and patient treatment, with repeated observation, was required. In the various details of washing, and during micro-chemical investigation, the wellknown refractory properties of mucilage were only too well marked, rendering much of the necessary manipulation both trying and tedious.

1 This method was first used for the tentacles of Drosera. See Gardiner in Proc. Roy. Soc. 240 (1886).

This applies to Blechnum only. The hairs of Osmunda contain sach an enormous quantity of tannin that the whole of the tincture is blackened. 


\section{Special ObServations.}

(a.) Blechnum occidentale, L.

This species was used in preference to Blechnum brasiliense, Desv., both because it demonstrated more clearly the minute histology of the gland-cells, and also on account of its freely branching habit which ensures the production of a sufficient supply of growing points. The stem is provided with numerous paleae, and both on the structure and on the young leaves there are numerous mucilage and resin-secreting glandcells (Figs. I, 2, and 3). In each of the paleae the apex is terminated by a single mucilage-gland borne on a long stalk which is filamentous and multicellular. This stalked gland is developed at a very early stage in the history of the scale (Fig. 4), and by the time the rest of the glands are produced along the scale-edge, and have become functional, the apical cell has perished and its contents have usually quite disappeared (Fig. 1). With the exception of this terminal cell which always secretes mucilage, the remaining glands may be either entirely mucilaginous or entirely resinous in character, or in many cases both forms may occur. The resinglands are usually simple and sessile, and the secretion appears outside the cell-wall, collecting beneath the cuticle which becomes raised up like a blister, as in so many resin and oil-producing hairs (Fig. 31). The mucilage-glands are usually stalked and the secreting cell is large and swollen, but the secretion escapes in this case only on the rupture of the cell-membrane (Fig. 27). The foregoing remarks upon the anatomy of the paleae-hairs will equally apply to those of the leaves. Both mucilage and resin-glands occur distributed over the surface. The mucilage-hairs are especially localised in relation to the vascular bundles, and rows of them arișe from those epidermal cells which are placed immediately above the main vascular trunks. In like manner the resinhairs are met with in greatest number along the edge of the young leaves. Having teased out and mounted a preparation 
of young paleae and leaves, the attention of the observer is soon drawn towards the large swollen mucilage-cells. They may be seen in various stages of development, and perhaps the more usual and typical forms are those represented by Figs. 5, 6 and 7 .

The glands of the paleae are more conspicuous than those of the leaf on account of their greater size and the more highly refractive character of the mucilage secreted by them. The latter substance occurs in the younger glands as a number of brightly shining isolated drops (Fig. 5), which soon appear to lose their distinct outline and to become clubbed together - into a single irregular and lobular mass (Fig. 6). Later on, the entire cell appears to be filled with the mucilaginous secretion, which is highly refractive and contains a number of darker granules disseminated throughout its substance (Fig. 9). In other gland-cells the mucilage appears to be differentiated into an inner and granular central mass surrounded by a broad and hyaline outer layer (Figs. 7 and 8 ), and here almost any one would suppose that at any rate a portion of the mucilage arises from the degeneration of the inner layers of the cell-wall. Lastly, careful observation will usually demonstrate that in the isolated drops which are shown so well in the younger gland-cells, numerous minute droplets are present which may moreover be recognised in the older glands also (Figs. IO, I I, I 2 and 8). The protoplasm is in all cases clear and difficult to define.

We may at once remark that in reality all the mucilage is secreted by the protoplasm, and that in the very oldest cells remains of the ectoplasm and of the nucleus can be shown to be present outside the mucilage-mass. The very transparent character of the protoplasm causes the satisfactory demonstration of this fact to be often a matter of some difficulty, and we found this to be especially the case in our investigations concerning the origin and development of the mucilaginous drops. Again and again, from every standpoint we have returned to this question, and after numberless observations we feel that we have established beyond all doubt that the whole of the 
mucilaginous secretion is entirely intra-protoplasmic, and that the cell-wall takes no part whatever in the phenomenon.

The earliest stage of development of the secretory hairs is indicated by the arising of a papillose outgrowth from one of the ordinary epidermal cells. This may be a cell occupying any position in the case of a young leaf, but in the paleae it must be one which is situated along the edge of that structure. The papilliform protrusion is soon cut off by a transverse wall and may then again divide once or several times (Fig. I4). It is always the apical or head-cell which exhibits the secretory function. All the cells both of the leaves and paleae possess large and distinct nuclei, and numerous plastids are also present. No movement of the protoplasm of the stalk-cells could be detected as in the case of Ononis spinosa, L. ${ }^{1}$ Even more markedly than the rest, the young gland-cell exhibits the well-defined nucleus and plastids of which we have spoken, and here the commencing vacuolation and the delicate strands of protoplasm, stretching on all sides from the nucleus to the peripheral lining of the cell-wall, appear to exquisite advantage and beauty (Fig. I5). As the cell grows the usual single vacuole is formed and the protoplasm takes up its well-known position, lining the rapidly enlarging cell-membrane as a delicate primordial utricle. Both the nucleus and the plastids are then found to be situated on the inner side of the ectoplasm as in Chara ${ }^{8}$. The secretory change first begins in the endoplasm, commencing just beneath its free surface and simultaneously over the entire area which immediately bounds the cell-vacuole (Fig. 16). It then spreads into deeper and deeper layers until the whole of the endoplasm takes part in the process. After some time the plastids are gravely affected by the various changes which are taking place, and they eventually become disorganised, and disappear, yielding up their own substance to contribute to that of the secretion. In the nucleus also, great degeneration occurs, and at the period of rupture of the

\footnotetext{
${ }^{1}$ Behrens in Ber. deutsch. bot. Gesellschaft, Bd. iv. (1886), p. 402.

'Sachs's Tertbook of Botany, and Engl. ed., p. 304
} 
cell-wall and escape of the secretion the ectoplasm and the disorganised nucleus are the only structures which still remain in connection with the cell-membrane, the dead and equally disorganised endoplasmic framework escaping with the mucilage (Figs. 9 and 27).

Tannin can be demonstrated in quite young cells, and from this point onwards it steadily increases in amount, although it never occurs in such great quantity as in Osmunda. With the exception of its transverse basal wall the cell-membrane undergoes cuticularisation over the whole of its surface, but it is only the more external of the wall-lamellae that are thus affected. The inner layers retain for some time their primitive cellulose character, but at length they suffer hydration and become converted into a substance of a mucilaginous nature. This latter, although it undergoes but little swelling, is capable of great extension, as the very large size of the bladder-like glands sufficiently proves. The transverse basal wall, which separates the head from the contiguous stalk-cell, is much more pronouncedly mucilaginous, and gives a well-marked pink colour with corallin-soda.

We are now in a position to describe in detail the various phenomena connected with mucilaginous secretion. We have already stated that this substance is directly derived from the protoplasm, and we may further add, that the various changes which give rise to its formation are undoubtedly of a katabolic nature. In all the cases which we have investigated the mucilage arises in the form of small drops, all of which grow to a fixed definite size, and the number of the drops is continually increased by repeated basipetal formations until the energy of the protoplasm is exhausted and the gland-cell is full (Figs. I6 and I7). The first few drops appear to burst into the vacuole, causing it to assume a certain mucilaginous character, but, apart from this exceptional phenomenon, all the various drops remain distinct, each being completely shut off from its neighbour by its own portion of the delicate protoplasmic reticulum which constitutes a framework for the whole system of drops in the secretory cell. 
The successful observation of the developing drops was found to be one of the most difficult points connected with the present research, but by the use of osmic acid we were at length able to set the matter at rest, and subsequently also to observe the same phenomenon in fresh glands. As our figure (Fig. I6) shows, the development commences at a very early period. Our drawing was taken from a hair which had been treated with a I per cent. solution of osmic acid. The mucilaginous contents of the vacuole are contracted by the action of the reagent, leaving a portion of the lining protoplasmic membrane and of the threads going to the nucleus clear and free. At various points here and there numerous small bubble-like utricles may be seen, and these represent the young developing mucilage-drops. The secretion arises, as we have already stated, just below the surface of the endoplasm, and the drop, enclosed by its delicate protoplasmic membrane, protrudes into the cell cavity. Having reached a definite size, its growth ceases and a new drop soon commences to form just below, and thus by repeated basipetal formations immediately beneath the various drops contained in the cell, the latter becomes after a time quite filled by them and even the vacuole-space is entirely eliminated. Fig. I7 shows in a very clear manner the formation which we have described. In the adult cell the protoplasm appears as a delicate reticulum containing the various drops in its meshes, the whole system being bounded by the ectoplasm and contained within the cell-membrane (Figs. II and I9). All the protoplasm is for some time living and functional, but in course of time it experiences degeneration-changes, and ultimately death ensues, commencing in the more central protoplasm and gradually spreading to that at the periphery. The remains of the disorganised framework may be brought into view by staining the cell with iodine when it appears as a number of deeply-staining granules which still mark out the boundaries of the separate mucilage-drops (Fig. I9). In the fresh and fully-developed cells, especially of the leaves (Fig. 20), it is often indistinguishable, but may be readily demonstrated by the use 
of either iodine or osmic acid. The secretion is produced mainly at the expense of the endoplasm and of the substance of the plastids. As we have remarked before, the remains of the ectoplasm and nucleus may always be recognised, and they are usually left behind after the escape of the secretion (Figs. 27 and 29). The changes which occur in the drops themselves are of great interest. At their first formation the young drops are watery and by no means well defined. By the use of osmic acid it can be demonstrated that at this stage they contain no tannin. They shortly become denser and more highly refractive, and tannin makes its appearance equally distributed throughout their structure. Osmic acid then gives very striking results, for the separate drops are blackened by the reagent while the protoplasmic reticulum takes practically no stain, and thus the contrast between the two is sharp and well defined. And now in the drops themselves a delicate reticulation may be observed, which finally gives way to the appearance of numerous minute and brightly shining droplets, all separate and distinct, disseminated throughout the substance of the drop, just as the drops themselves are disseminated through the substance of the secretory protoplasm (Figs. Io and I3). The droplets do not contain tannin, and osmic acid stains the ground substance only. We have thus been able to trace a wonderful series of changes, which must from a chemical point of view be of a most interesting character, but which at present we cannot with certainty explain. Methyleneblue confirms the results obtained with osmic acid. This substance, as Klebs ${ }^{1}$ has shown, is capable of forming with tannin a definite compound: and we ourselves have observed that the staining produced by the dye in structures containing tannin is one which is both distinct and easy to be recognised, especially when viewed through yellow light, such as that produced by an argand burner. The coloration, namely, is a somewhat dull purple blue, not unlike that produced by haematoxylin, and stands out in marked contrast to the usual

${ }^{1}$ Klebs in Untersuch. \&. d. bot. Institut z. Tübingen, 1886 . 
bright and pure azure of the normal methylene-blue stain. In the present instance the minute and brilliant droplets assume the clear azure colour, while the substance of the drop is of the dull murky purple to which we have already referred. We may pass on to other reactions of the mucilaginous secretion in the gland-cells. With iodine and chlorzinc-iodine (Schultze) it undergoes just the slightest blue coloration. With Hanstein's reagent it stains reddish purple, and with picronigrocin steelblue. When carefully treated with Hofmann's blue it does not stain, and therein differs from the protoplasmic reticulum which colours well and becomes clearly demonstrated. With corallin-soda there is no conspicuous staining. The drops and droplets are but little affected by either hot or cold water beyond mere swelling, but they dissolve or rather become invisible in dilute potash, often leaving the protoplasmic reticulum exceedingly well defined.

We are at present unable to state with any definiteness what is the exact nature of the bodies produced during the various stages of secretion, but from the above reactions we believe that in the mature and fully developed drop the ground-substance consists mainly of gummy mucilage, while the droplets themselves consist of pure gum. The reaction with iodine and chlorzinc-iodine seems to indicate that the mucilage is allied to certain forms produced by the hydration of cellulose-structures. Thus the protoplasm gives rise to some body producing a gummy mucilage, and the latter is further split up into a gum and a gum-mucilage residue. The reticulation which appears in the young drop, and precedes the formation of the droplets, is a phenomenon of great interest, and seems to indicate that the substance first produced by the protoplasm is in a state of high organisation, if not actually living; but this can only be settled by careful observation and elaborate experiment. At present we have no data which throw any further light upon the subject.

With alcohol or with plasmolysing reagents the whole mucilaginous contents undergo great contraction but return to their normal bulk upon the careful addition of water. Plas- 


\section{in Blechnum and Osmunda.}

molysis also affords striking proof that the mucilage is entirely contained in the endoplasm and does not arise from the cellmembrane, for at any stage during secretion the protoplasmic body may be withdrawn from the wall to which it is always connected by numerous fine fibrils and delicate threads, and it can then be plainly seen that the whole of the mucilage is included within the shrunken utricle (Figs. 22 and 23).

From the point of view of visibility both the drops and droplets vary considerably. In some glands where the mucilage is dense and the protoplasmic reticulum well defined, the structure is very obvious without any special preparation (Figs. 5, 6, Io). In other cases the reticulum appears to be less marked (Fig. 20), the mucilage less dense, and the droplets but feebly defined and little developed. Such glands require careful observation, and a cautious and well-regulated use of reagents, to demonstrate that their actual structure is that which we have described. Other glands appear to form an abnormal amount of tannin (Figs. 24,25 and 26), and these are the most difficult to deal with. The drops and droplets are never so clear in this case and are sometimes even scarcely to be distinguished. Finally, and as a very common phenomenon, there is a marked difference in appearance between the cortical and peripheral mucilage (Figs. 7 and 8). This is mainly due to the difference in pressure with which the two systems meet. The first-formed drops bud out freely into the cell-cavity, while those produced later on, by the repeated basipetal formations, come into existence when the cell is fairly full of drops, and are thus soon exposed to great pressure on all sides, and being densely packed appear to be more highly refractive than those of the central core. Apart from this, the structure of both forms appears to be quite similar, but the density of the drops and droplets varies greatly.

The cell-contents usually escape by means of a small localised rupturing of the wall (Figs. 9 and 27), and the various drops are turned out, both by the elasticity of the wall, the feeble contractility of the ectoplasmic remains, and 
by the swelling of the mucilage both of the inner layers of the cell-wall and of that of the drops themselves. The combined effect of these various forces produces a very practical result, and the drops escape with some rapidity from the ruptured gland. In ordinary circumstances water penetrates with great difficulty through the cuticularised wall. Thus we found, when testing with osmic acid, that the reagent penetrated by means of the basal transverse wall and by way of the stalk-cell infinitely sooner than through the exposed cell-membrane. When therefore a rupture occurs, there is quite a rush of water and great swelling of all the mucilaginous structures. Another mode of escape also occurs (Fig. 28). In this case there is no rupture in the real sense of the word, and the phenomenon only takes place in old cells which have hitherto remained imperforate. The whole wall through disorganisation gradually breaks down on all sides and the swollen drops quietly escape.

We have yet to mention a small matter of some interest in connection with the mucilage-glands, and this is that in Blechnum occidentale we always found a fungus associated with the growing point. The growth of the mycelial filaments proceeds pari passu with that of the young shoot, and even manages so to distribute the numerous hyphal branches over all the young structures that, by the time the various mucilage-cells are ready to rupture, there is always some attendant hypha near at hand. As soon as the contents have escaped, this hypha grows into the ruptured cell by means of the orifice and soon makes strong growth, obtaining apparently much sustenance from what remains of the ectoplasm and nucleus (Fig. 30). We have not cultivated this fungus and are consequently unable at present to state any further details.

Before concluding our description of Blechnum occidentale we may perhaps make some remarks concerning the resingland-cells. We have already described their development and stated that their structure is somewhat simpler than that of the mucilage-glands. It is a matter of great interest that 
in the same plant, and even on the same scale, there should be two forms of hairs practically identical in development, distribution, and even in their broad plan of structure, one of which should secrete mucilage, and the other, by some difference (possibly a slight one) in the metabolism of its protoplasm, should give rise to resin. It is a phenomenon which is certainly worthy of more investigation, but for the present we have confined ourselves to the question of mucilaginous secretion, and we can now do no more than give just the slightest description of the structure of the cells and the mode of secretion of the resin. Each cell contains a lenticular and very distinct nucleus, and the protoplasm is exceedingly granular in the functional cells, especially towards the head, where the nucleus and the main mass of the protoplasm is situated (Fig. 32). A single large vacuole is generally present at the base of the cell, and here the utricle is thinner and hyaline. The secretion collects only under the head of the gland, so that the bladder does not surround the whole free surface (Fig. $3^{1}$ ). The resin gives the usual reaction with alcannin, and in certain cells it was recognised both under the cuticle and in the cell-contents. We think there is little doubt that the mode of development of the resin is similar to that of the mucilage, and that some formed body, produced by the activity of the protoplasm, is present as a series of metaplasmic drops, and undergoes further changes before the final production of resin.

\section{(b.) Osmunda regalts, L.}

We have seen that in Blechnum occidentale the young bud is adequately protected both from mechanical injury and also from abnormal variations of temperature and moisture by the numerous paleae and by the secretory hairs of the paleae and leaves. In Osmunda a similar provision occurs, but the details of the arrangement are somewhat different. In this case paleae are absent, and it is the base of the leaf-stalk, here winged and sheath-like, which acts as a protection against injury from without and also bears the mucilage-cells (Fig. 
$33)^{1}$. No resin-secreting hairs are present, and on the young lamina only woolly hairs are to be found. The mucilageglands occur on both sides of the young leaf-base, and are unbranched and filamentous. All the cells of the filament are usually glandular, so that, unlike Blechnum occidentale, there is here a row of secreting cells and not a single terminal gland (Fig. 34). The non-secreting woolly hairs are long and branched, and cover the young lamina with a dense felt which affords an excellent protection against extremes of temperature (Fig. 35). The development of both forms of hairs is essentially the same, and it is only in their subsequent behaviour that they so markedly differ. They first arise as outgrowths of epidermal cells which are subsequently cut off by a wall from the general cell cavity (Figs. $3^{8}$ and 39 ). The small cell thus produced is the mother-cell of the hair, which soon divides freely and produces a long filament (Fig. 34). In the case of the mucilage-hairs the growth is strictly basipetal, and the hair is almost always simple and unbranched. The woolly hairs on the contrary may also elongate by means of apical growth, and branching with them is the normal and usual phenomenon. The young cells contain each a nucleus, usually provided with two, or sometimes three, well-marked nucleoli, and several plastids.

As the cells grow they gradually become vacuolated, and, as in Blechrum, the nucleus is situated on the inner side of the ectoplasm in the mature cell. At an early stage the plastids divide and soon produce numerous starch-grains (Figs. 34 and 35), which in the young cells occur in the bridles of protoplasm stretching from the nucleus, and, later on, become distributed all round the primordial utricle. They then occupy a position similar to that of the nucleus.

\footnotetext{
1 According to Prantl (see Sadebeck in Schenk's Handbach, Bd. i. p. 274) the ontermost young leaves of each winter-bud become peculiarly modified and scalelike, having for their function the protecting of the youngest and innermost members. Since our research was undertaken in October 1886 and finished in April 1887, we were working principally upon winter-bads provided with the modified leaves.
} 
We may now confine ourselves to the consideration of the secretory hairs, dealing with the woolly hairs later on. The free walls of the mucilage-cells become markedly cuticularised but the transverse walls undergo a mucilaginous change. It soon becomes manifest that they also experience a great increase of thickness on either side, and reagents demonstrate that the thickening layers are of the nature of callus. Further, one can observe a phenomenon of great interest, for both the wall and the callus-layers on either side are perforated by a number of fine holes, which may be readily recognised even by direct observation and without the use of reagents (Figs. $3^{6,4}, 4,43$ ). A similar perforation of the transverse walls has already been described by Behrens ${ }^{1}$ as occurring in the secretory hairs of Ononis spinosa, but in this case there is no callus present. The structure presented by Osmunda regalis is very like that of certain forms of callosed sieve-tubes, and in its mode of arrangement - the transverse wall and its two callus-plates-it even more strongly resembles that described by Schmitz ${ }^{2}$ for so many of the Floridex. We think it hardly necessary to refer at any length to the importance of these perforations in establishing a continuity of the protoplasm between the various adjacent filament-cells, since one of us $^{3}$ has already treated of the subject in some detail, but we would only wish to point out that its existence affords yet another proof of the porosity of the cell-wall, and of the very intimate connection which probably exists between all the constituent cells of living plant-tissues. The mucilaginous and callosed wall also serves a most important function in connection with the discharge of the secretion, for whereas the cuticularised walls are both resistent and impervious, the transverse membranes readily take up water, and, rapidly swelling on all sides, they finally cause the rupture and separation from one another of the secretory cells of which the adult

${ }^{1}$ Behrens in Ber. deutsch. bot. Gesellschaft, Bd. iv (1886), p. 402.

- Schmitz in Sitzber. Akad. Wiks. Berlin, 1883 , p. 215.

1 Gardiner in Arbeit. a. d. bot. Institat 2. Würzburg Bd. iil. p. $5^{2}$. 
hair is composed, and the escape of the mucilaginous contents is then a very easy matter (Fig. 44). In certain instances, however, the rupture and escape takes place as in Blecknum.

The mucilage of the mature glands when examined in water appears dense and horny. As in Blechnum brasiliense there is a marked distinction between the looser and more granular central core (Fig. 40) and the highly refractive and lamellated peripheral portion of which the bulk of the secretion consists. On the addition of alcohol the layering becomes much more evident, and at least three well-defined zones may then be distinguished (Fig. 43); the peripheral portion, already referred to, undergoing further differentiation into two or more concentric strata. This separation into layer's evidently depends upon the constitution and tension of the various parts of the mucilaginous secretion. The centremost portion represents the first formed mucilage as in Blechnum brasiliense. The most external and densest layer is, on the contrary, of the more recent formation. It is exposed to some pressure and it differs also in constitution, since, as we shall see further on, starch largely enters into the composition of it. The middle zone consists of mucilage practically free from starch, being derived purely from the inner portions of the endoplasm ; and here the pressure is the greatest of all, since it is situated between the central core which; being most disorganised, swells to the maximum and refuses to yield, and is also exposed to the pressure of the outer zone in which new drops are continually being formed and pushed towards the centre. See also Fig. 40, which shows relative pressure of drops.

We may now describe the mode of secretion. If in Blechnum brasiliense it appears that the mucilage is partly derived from the cell-wall, so much the more is this the case in Osmunda, where even the layering which accompanies ordinary mucilaginous degeneration is wonderfully simulated (Fig. 44). Goebeler ${ }^{1}$, indeed, actually states that the mucilage

1 Goebeler, loc. cit. 
does arise from the inner layers of the cell-membrane, but de Bary ${ }^{1}$ with his customary caution merely remarks that 'the origin of this mucilage has yet to be investigated.' As a matter of fact the development is precisely similar to that which we have described in Blechnum. Here also the secretion arises in the form of isolated drops, which at first bud into the cell-cavity, and are subsequently increased basipetally until the cell is full (Fig. 40). In Osmunda the drops are both smaller and more numerous. In each drop a further differentiation into droplets takes place, but the comparative difference of density of the two structures is not nearly so great and as a consequence the droplets are somewhat difficult to define, but by appropriate swelling in water and staining in methylene-blue the whole structure may be clearly seen. In the denser peripheral mucilage even the drops themselves are difficult to distinguish without preparation, and the protoplasmic framework is slight and fine. Neither chromic nor osmic acid can be employed for the examination of the fresh hairs on account of the enormous quantity of tannin, which stains the whole structure so deeply as to render satisfactory observation quite impossible. Iodine gives striking and beautiful results, and, as our figure (Fig. 40) shows, one may bring out in the mature cell the nucleus, the drops, and the framework with great distinctness and effect. See also Fig. 4r, where the drops are seen from the outside. The secretion of the drops commences in very young cells, and some of the drops first formed appear to burst into the cell-vacuole as in Blechnum. For a long time the starch, which is present in the cell in great quantity, takes no active part in the drop formation, but, as the zone of secretion spreads, they gradually break down and disappear. The degeneration, both of the starch grains and of the nucleus, is usually accompanied by the frothy and utriculated appearance which characterises such degenerations as that of the chlorophyll-corpuscles of Chara

\footnotetext{
${ }^{1}$ De Bary, loc. cit.
} 
when caused by the action of water, and it is often a matter of difficulty during the later stages of secretion to distinguish the bubble-like appearance connected with the true dropformation from the somewhat similarly utriculated starchgrains, and portions of the nucleus also. In no case does the whole of the nucleus disappear, but the starch-grains become entirely disorganised and destroyed. Not unfrequently irregular lumpy masses of callus occur on the side walls of the cell, and equally with the callus of the transverse walls they appear to be formed, at least partly, from the starch-grains; thus confirming the view that callus is of the nature of a starchy mucilage ${ }^{1}$.

The mucilage of Osmunta is of the same nature as that of Blechrum, and gives similar reactions. Certain phenomena occur in consequence of the action of corallin-soda, which are perhaps deserving of mention. In the first place, the protoplasm adheres with great tenacity to the transverse walls, and, even after death, the main protoplasmic body is connected to them by numerous fine filaments. This is of some interest in connection with the perforation of which we spoke. Secondly, a number of delicate utricles arise on the free surface of the protoplasmic body; these appear to owe their formation to an external secretion of mucilage, induced by the deleterious action of the somewhat concentrated solution of sodic carbonate (Fig. 42).

We have already alluded to the mode of rupture of the cells and the escape of the secretion. The mucilaginous contents escape in one large mass, which soon swells and disorganises. Very commonly the ectoplasm and what is left of the nucleus remain in the cell after the secretion has escaped, and thus afford further proof that all the mucilage is derived directly from the endoplasm and is enclosed by the ectoplasm. The protoplasmic framework breaks down and becomes granular as in Blechnum. The amount of slimy and stringy mucilage, which results from the addition of water to the free secretion,

1 Gardiner, in Camb. Phil. Soc. Proc., vol. v (1883), p. 230. 
is perfectly enormous and much greater in quantity than in Blechnum. In Osmunda no fungus was found to accompany the young leaves, the increased amount of tannin being perhaps unfavourable to the mycelial growth.

The fate of the woolly hairs is quite different from that of the glands, notwithstanding the similarity in the mode of development. Their cell-wall, which in the adult cells is often of very appreciable thickness, permanently retains its cellulose character and does not become cuticularised. The starchgrains gradually disappear from the mature cells, and on some of the transverse walls a callus may occur. In many of the cells the contents especially devote themselves to the formation of tannin, in which case they appear clear and highly refractive. In the very oldest cells the contents entirely disappear. With these remarks we end our description of Osmunda.

\section{Generai. Results.}

The secretory hairs which we have now described are characterised by a peculiarity rarely met with in glandular trichomes, in that the secretion does not leave the cell but remains included in the protoplasmic body throughout its entire life. The continuous aggregation, the manner of secretion, and the dense and solid character of the substance thus formed, enable us to understand how it is that in these particular glands the structure is clear and well-defined.

The secretion commences by the breaking down of a portion of the innermost layers of the endoplasm at a number of contiguous but isolated areas. The first secretion occurs just beneath the free surface, and takes place equally around the whole cell-cavity, and the phenomenon steadily continues from within outwards, extending to deeper and deeper layers, until the whole of the endoplasm, together with the substance of the plastids, have taken their share in the process. We are unable to state whether these changes are limited to the endoplasm only, since the exact boundary between the ectoplasm and endoplasm cannot be defined. In the present state 
of our knowledge we should not think it well to attempt to separate too sharply the structures which we have hitherto regarded as merely differentiated parts of the same body, and we would therefore prefer to state the case thus: that whether the ectoplasm contributes or not to the secretory changes, yet in all cases a very conspicuous portion of it remains, which is associated also with the remains of the nucleus.

In the special instance before us the vacuole does not persist for any length of time, for its cavity soon becomes obliterated; in the first place, in consequence of the very voluminous character of the secretion, and subsequently, because of the disorganisation of the bounding membrane (hautschicht) which until then had shut off the contents of the vacuole from the general protoplasmic body. The secretion, as we have seen, is not turned out of the cell, but continually collects and aggregates, and its remarkable swelling properties cause it to become very bulky, and to take up the whole of the available cell-space. It would, perhaps, appear at first sight that the vacuole takes some definite part in the secretory changes, but bearing in mind the mode of first formation, and taking into consideration the phenomena which occur in other secretory cells, we are led to conclude that the secretion is strictly intraprotoplasmic, and that neither the vacuole nor its contents take any direct part in the actual secretory process ${ }^{1}$.

We found that the secretion was produced as a number of isolated drops, and we have just explained that they are situated in the substance of the protoplasm. They are doubtless produced as a result of katabolic change, and must be regarded as coming under the head of metaplasm or formed substance. We have described in detail the sequence of

\footnotetext{
${ }^{1}$ A secretion being once formed, it may of course pass either to the exterior or interior of the cell. We have examples of both cases in Blechnum accidentale, for in the mucilage-hairs some few of the drops excape into the cell-vacuole, and in the resin-hairs the secretion passes to the ontside and appears beneath the cuticle. We may add here that what is true of the special substances which we are accustomed to regard as secretions or excretions par excellence, e.g. oil, resin, \&cc., is probably true also of many other substances, nutritive and non-nutritive, which occur in the cell-pacuole.
} 
changes which ensue during their secretion, and we found that the drops appear to consist in the first instance of a clear gummy mucilage. This substance experiences further change, and in the fully developed structure we are able to distinguish, in each drop, a number of secondary spherical droplets which now give the reactions of pure gum. Thus the protoplasm gives rise to a 'gummy mucilage, and the latter undergoes further differentiation into a ground-substance, which still retains its mucilaginous character, and into a gummy substance (the product probably of maximum chemical change) which is present as a number of isolated spherical droplets.

In the mature gland the various drops are disseminated throughout the substance of the protoplasm, so that the protoplasm itself appears as a delicate reticulum or framework which contains the various drops in its meshes. It is a point of great interest to us that our results tally in a most remarkable manner with those obtained by Langley, in his research on the structure of animal secreting glands. We may even compare his description with our own, and if we provisionally eliminate from consideration the cell-wall, the cell-vacuole, and the plastids as being especially associated with plant cells, it will be seen that there is a great similarity between the two structures. The particular paper we quote from appeared in the 'Proceedings of the Cambridge Philosophical Society ${ }^{1}$ '. We necessarily somewhat condense Langley's remarks. He writes, 'The secretory glands have the following common points of structure. The cell substance is composed of $(a)$ a framework of living substance or protoplasm, connected at the periphery with a thin continuous layer of modified protoplasm ${ }^{2}$. Within the meshes of the framework are enclosed two chemical substances at least, viz. $(b)$ a hyaline substance in contact with the framework, and of $(c)$ spherical granules which are imbedded in -the hyaline substance.' We do not wish to press the similarity too far, since we are aware that in establishing comparisons between

\footnotetext{
1 Langley in Proc. Camb. Phil. Soc., VoL v (1883), p. 25.
}

2 Onr ectoplasm. 
representatives of the Animal and Vegetable Kingdoms great caution must be observed. But we are nevertheless of opinion that a distinct unity both of plan and structure underlies all the similar phenomena common to the two great classes which constitute living beings, and that any apparent difference is one of degree and not of kind. In the case of certain animal glands, e.g. serous and mucous salivary glands, Langley concludes that the protoplasm forms the hyaline substance, and then out of this manufactures the granules which, during secretion, are turned out of the cell and give rise to the particular substance which the gland happens to secrete. The state of active secretion is followed by a period of rest during which the protoplasm grows, forms new hyaline substance, and from this again are produced new granules. We believe that a series of changes essentially similar in character obtain in certain plant-cells also. Usually speaking, plant-cells are incapable of such active and repeated secretion as occurs in those of animals, and in many instances, e.g. Blechnum occidentale and Osmunda regalis, the secretory changes occur in the cell once and for all, and at their termination the cell dies. But in other glands, e.g. those of Drosera, it appears exceedingly probable that the phenomena which accompany the repeated secretion are quite identical with those which happen in so many animal glands.

We have seen that, in the two mucilage-glands investigated by us, the secretion is not turned out of the cell during its lifetime, but in such cases as the resin-glands of Blechnum occidentale, where the secretion normally escapes, we may endeavour to offer some explanation as to the way in which the passage of the secretion to the exterior is brought about. For this purpose we may conveniently divide the secretions into (I) soluble and (2) insoluble substances. The soluble probably simply pass through the substance of the protoplasm by diffusion, but we must not omit to state that during this process the external membrane (hautschicht), the ectoplasm, must undergo some decided modification or change in relation to such special phenomenon. The insoluble secretions on the 
other hand have to work their way bodily through the protoplasmic membrane in order to escape to the exterior. This is probably brought about by a series of actual minute rupturings of the substance of the protoplasm, which no doubt at once heal, and the final escape to the exterior is possibly attended by the production of inflated bubbly protrusions, which burst in a manner essentially similar to that which occurs in the young cells of Osmunda and Blechnum in the case of certain of the first formed mucilage-drops. The passage through the cell-wall is a comparatively easy matter. Whether or not the cuticle is raised depends upon the density of the secretion and the degree of cuticularisation. Should the secretion, instead of escaping to the exterior, pass into the vacuole the phenomena are quite similar in detail, except that the inner membrane (hautschicht) of the endoplasm instead of the external membrane of the ectoplasm would have to be taken into account.

Botanical Laboratory, Cambridge, May 26, 1887.

\section{EXPLANATION OF FIGURES IN PLATES III \& IV.}

Figures I-32 illustrate Blechnim accidentate, except Fig. 4 (Ceralopteris thalictroides) and Fig. 7 (Blechnum brasiliense). Figs. 33-44 illustrate Osmutnda regalis.

(Where not otherwise stated the drawings are taken from fresh specimens.)

Fig. I. One of the paleze from the young shoot bearing numerous mucilage-glands.

Fig. 2. A similar palea bearing resin.glends.

Fig. 3. Apical portion of a very young bud, showing the young mucilage and resin-cells developed from the epidermal cells.

Fig. 4. Early stages in the development of Ceratopteris thalictroides (after Kny). The terminal cell which will become the mucilage-gland is atready well developed.

E 2 
Fig. 5. Mucilage-gland from young leaf representing the 'clear-drop' stage of the mucilaginous contents.

Fig. 6. A slightly older gland. The drops appear to have clubbed together into an irregular lobular mass. Rengents, or even careful examination of fresh material, show that the drops are in reality quite distinct from one another. The drops display a distinct granulation.

Fig. 7. Mature gland of Blechnum braviliense. The contents show a differentiation into central, dark and granolar core, and a clear and highly refractive peripheral portion, which exhibits signs of layering.

Fig. 8. Similar cell from the leaf of Blechnum occidentale.

Fig. 9. Terminal mucilage-gland from a palea, showing the granular macilaginous contents which apparently possess quite a homogeneons structure. In spite of the disorganisation, on account of the complete breaking down of the endoplasmic framework, the mucllage is still present as a number of isolated drops. These may be demonstrated by swelling with water, and staining with methylene-blue. Note the disintegrated nuclens and the mode of rupture.

Fig. ro. Gland from leaf. The drops exhibit differentiation into droplets. The nucleus and plastids are fairly well shown.

Fig. Ir. A stmilar gland from a palea.

Fig. 12. A similar gland from leaf at a later stage than Fig. Io.

Fig. 13. Several isolated drops from a leaf gland.

Fig. 14. Early stage in the development of gland-bearing hair. The terminal cell is that which becomes converted into the mucilage-gland.

Fig. 15. Older gland-cell. Note the nucleus, the plastlds, and the strands of protoplasm stretching from the nucleus. Vacnolation is now well marked.

Fig. 16. Gland from young leaf treated with osmic acid. The first fornation of the young macilage-drops may be observed taking place around the primordial utricle, and in the strands of protoplasm. Certain of the contents of the vacuole of a mucilaginous nature have become contracted by the action of the reagent.

Fig. 17. More advanced gland. The drops now numerous, and some even show the droplet stage. The basipetal formation of new drops is in this instance shown very clearly.

Fig. 18. Young cell after treatment with chromic acid. The clear spaces which mark the points of origination of the drups are seen from the outside. The halfdozen or so of the very clear circular spots, although they simulate the true formation, are in reality produced in consequence of the shrinking of the protoplasm from the wall at several small trolated areas, through the dehydrating action of the reagent employed. The impermeability of the mucilaginons cell contents causes the penetration of the reagent to take place with great difficalty, and often forces the protoplasm to give way.

Fig. Ig. Gland from leaf containing drops which exhibit but little definition. Note the nucleos and the protoplasmic framework. This gland was stained with iodine.

Fig. 20. Simllar gland with unusually clear contents. Drawn from fresh material mounted in water.

Fig. ar. Two glands from young leaf. The smaller is a resin-gland. The larger secretes mucilage, and shows the 'clear-drop' stage. 


\section{in Blechnum and Osmunda.}

Fig. 22. Young gland after treatment with ten per cent. sodium-chloride-solution.

Fig. 23. Older gland similarly treated. In this the drops were in process of formation.

Fig. 24. Gland in which the protoplasm has formed an unusual quantity of tannin. In osmic acid.

Fig. 25. A similar gland in its fresh state.

Fig. 26. A gland of the same nature as Figs. 24 and 25. Note the formation of drops and the peculiar position of the nucleus.

Fig. 27. Mncilage-gland undergoing ruptare. The remains of the nacleas and ectoplasm continue in the cell. The ectoplasm still shows on its membrane traces of the reticulation and arrangement associated with the formation of drops. In osmic acid.

Fig. 28. Second mode of escape of secretion. See tert.

Fig. 29. A cell after the escape of secretion. Remains of ectoplasm apparent.

Fig. 30. Ruptured gland, showing fungus-mycelium which is now feeding on the remains of the ectoplasm.

Fig. 3r. Resin-gland from palea. The secretion is collected ander the raised cuticle. In osmic acid.

Fig. 32. Resin-gland after treatment with picronigrocin. Note the lenticular nucleus and the protoplasm which is collected towards the cell-apex, and there exhibits marked granularity.

Fig. 33. Two views of a very young leaf of Osmunda regalis : $m=$ the places where the mucilage-hairs are to be found in the greatest number.

Fig. 34. Young mucilage-secreting hair. The cells are in various stages of development, and the growth is markedly basipetal. The starch-grains are especially situated in the protoplasmic strings, and in the upper cells the callosed and perforated transverse walls may already be observed.

Fig. 35. Young woolly hair. In the clear cells towards the aper the cells are particnlarly rich in tannin. (This hair is taken from a leaf which had been for a short time removed from the plant. The peculiar aggregation of the starch-grains in the protoplasmic strands is somewhat abnormal. In quite fresh cells they are found around the primordial utricle. Fig. 34 has also been somewhat affected by the treatment to which it was subjected.)

Fig. 36. Portion of a branched mucilage-secreting hair, showing the transverse walls and the two callus-plates belonging to each. The whole system (walls and callus) shows perforation.

Fig. 37. Portion of a young woolly hair cell with callus well developed on one side of the transverse wall.

Fig. $3^{8}$. Young stage of development of macilage-hair.

Fig. 39. Slightly older stage.

Fig. 40. Semi-diagrammatic optical section of mature mucilage-cell after treatment with lodine. Note the differentiation into layers, the drop-formation, the protoplasmic reticulam and the disorganised nuclens.

Fig. 41. A similar cell from the outaide. The mode of drop-development is quite apparent from this point of view. Some of the reticulation and formation of circular areolae is due to the disorganising starch-grains. The distinction between 


\section{Gardiner and Ito.-On Mucilage-cells.}

the two cannot be conveniently shown in a drawing, bat may be recognised with care, in the actual preparations, by the use of reagents.

Fig. 42. Mucilage-cells after lengthy treatment with thirty per cent. solntion of sodium-carbonate. The protoplasm withdraws with difficulty from the transverse walls, and is still connected with that structure by means of numerons delicate strands. Numerous external atricles have been produced by the action of the reagent.

Fig. 43. A mature cell after treatment with alcohol, showing the layering which is now so markedly demonstrated.

Fig. 44 Usual mode of rupture of mucilage-cell. 

Annats of Botany.

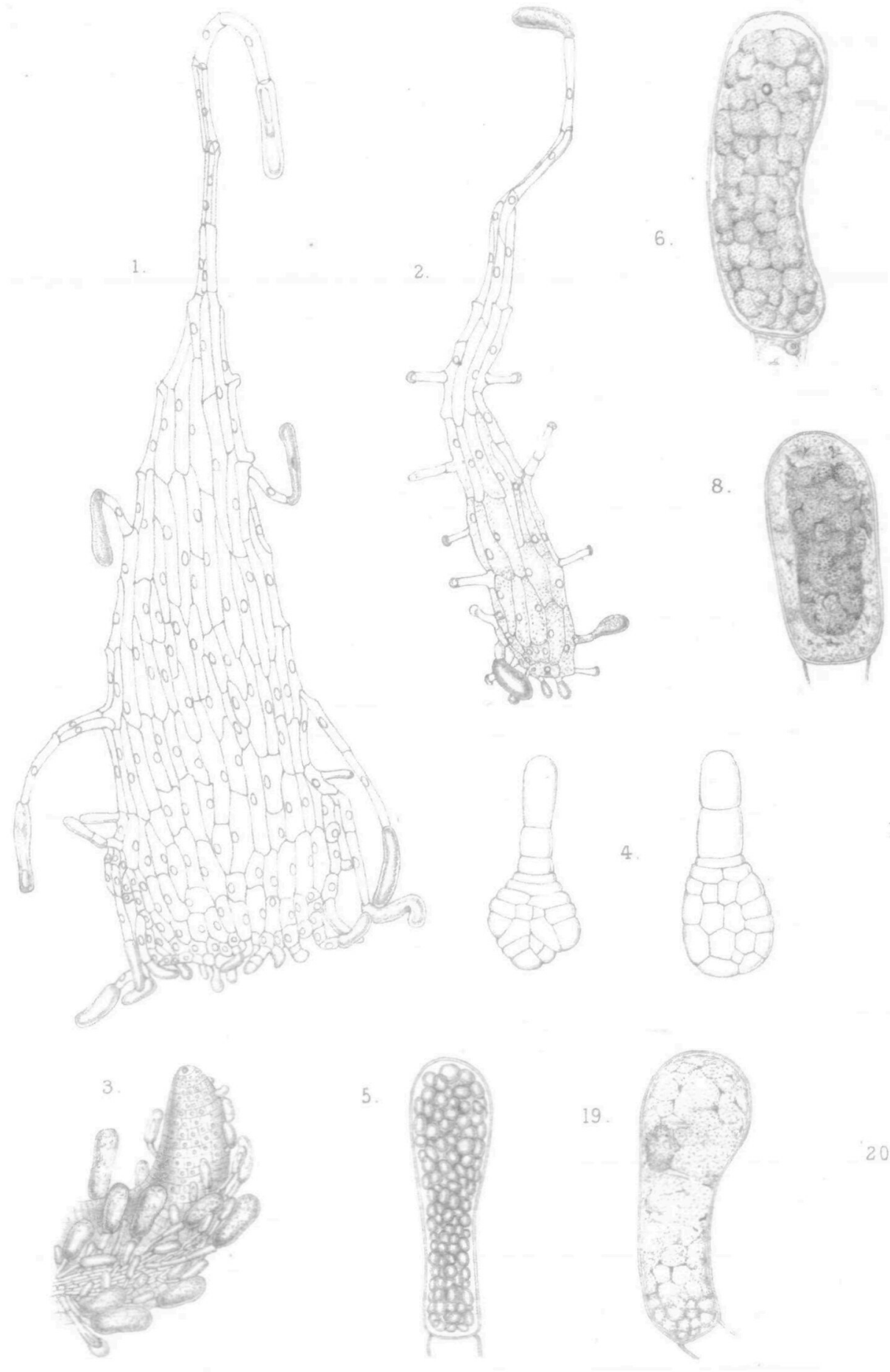

7. 


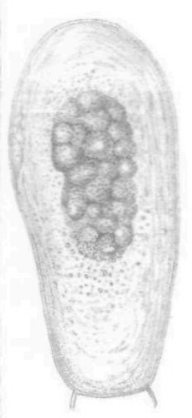

0.

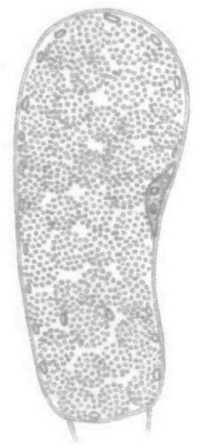

9.
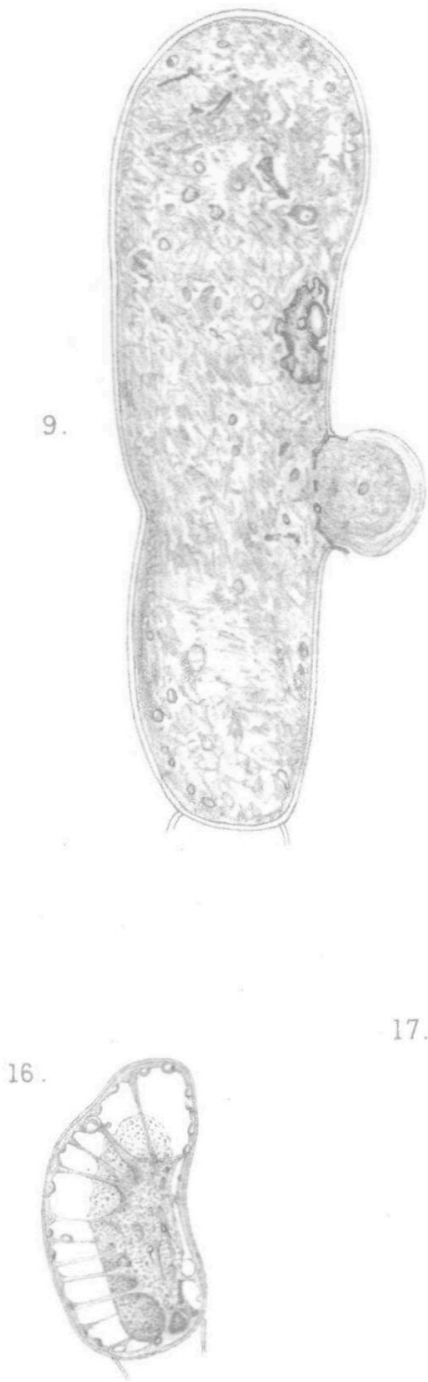

17
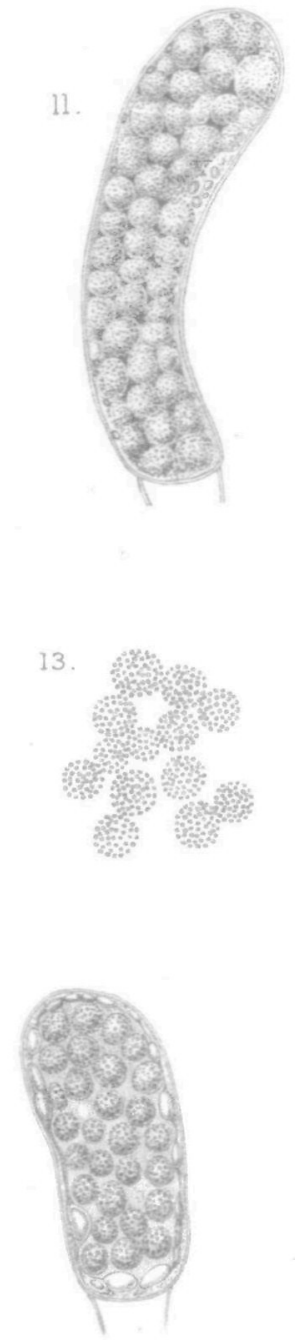

12.

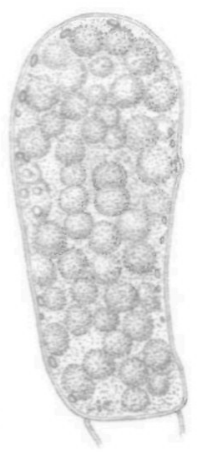

14.

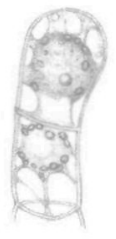

18.

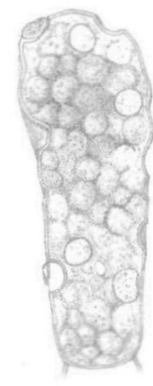

22.

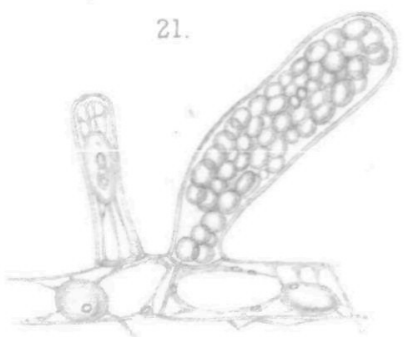

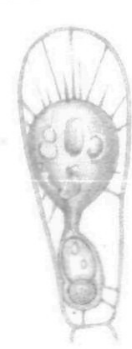

23

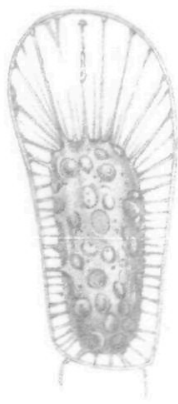




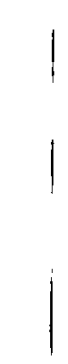

1

$\mid$

1 

Annals of Botany.

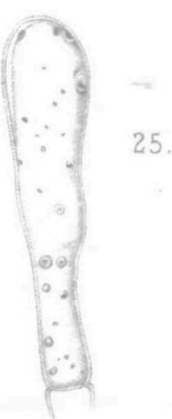

24.

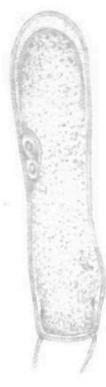

26.

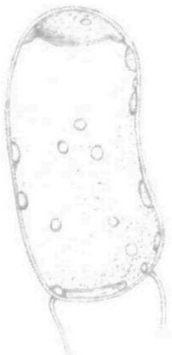

28.

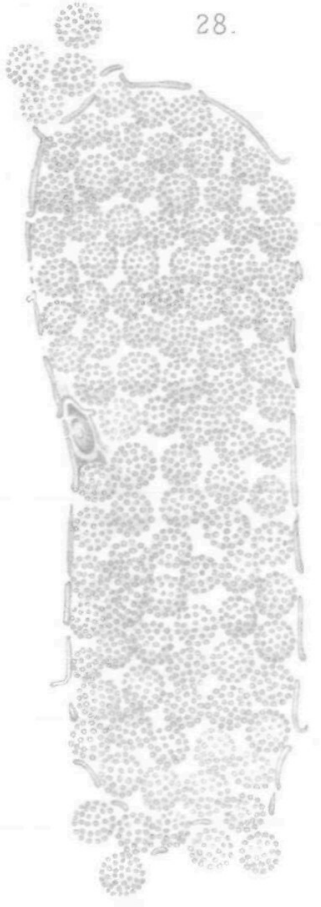

27.

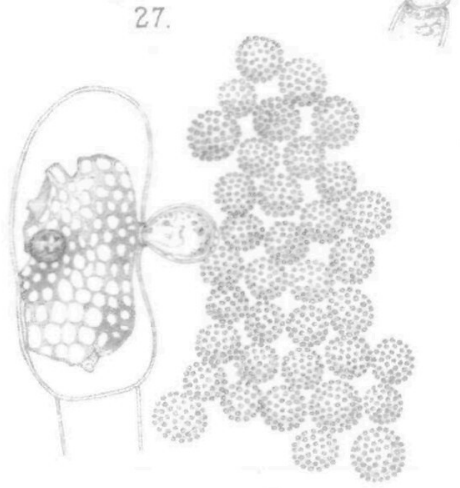

29.

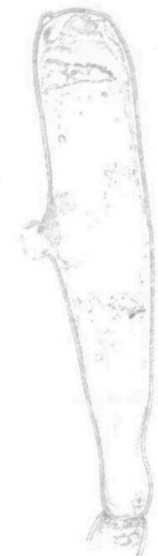

30.

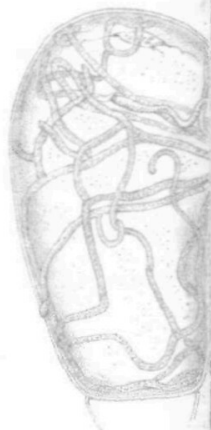

37

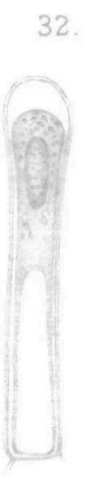

31.

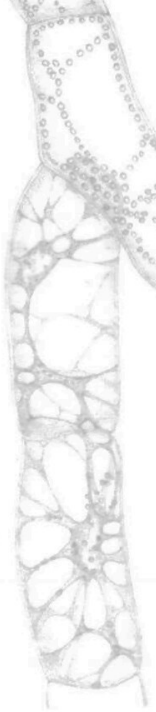

Tokutaro Ito del

GARDINER \& ITO.- ON MUCILAGE SECRETION. 
7

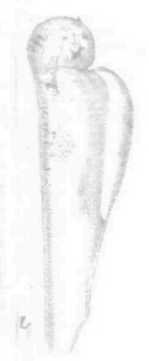

33.

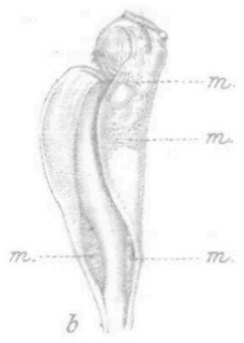

34.
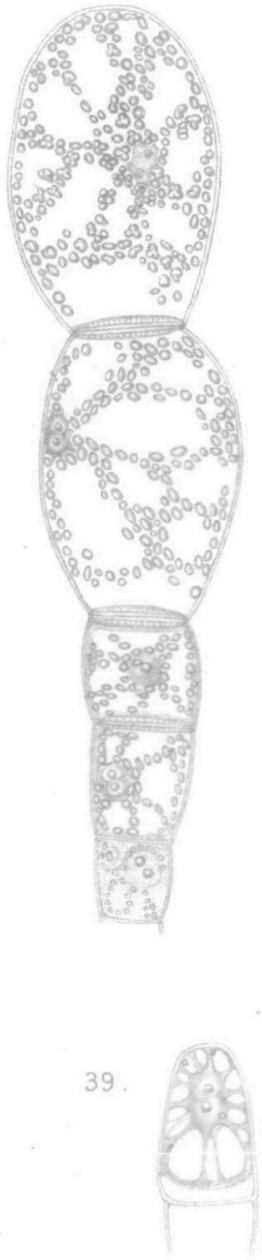

Vot.I, PV.IV.

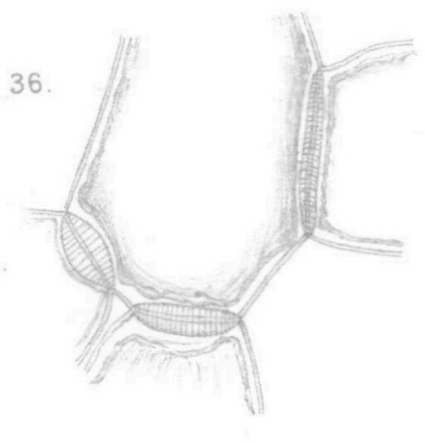

40

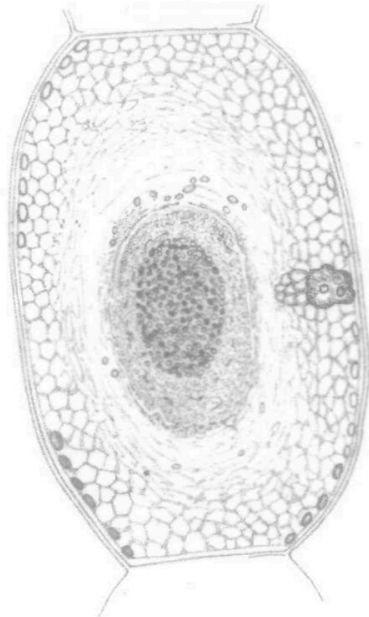

42.

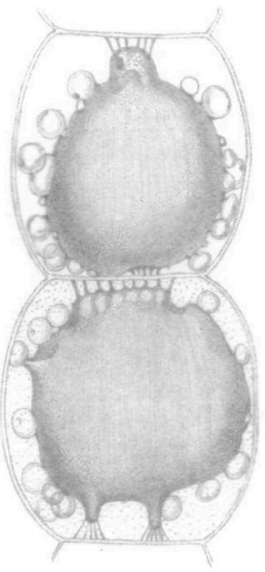

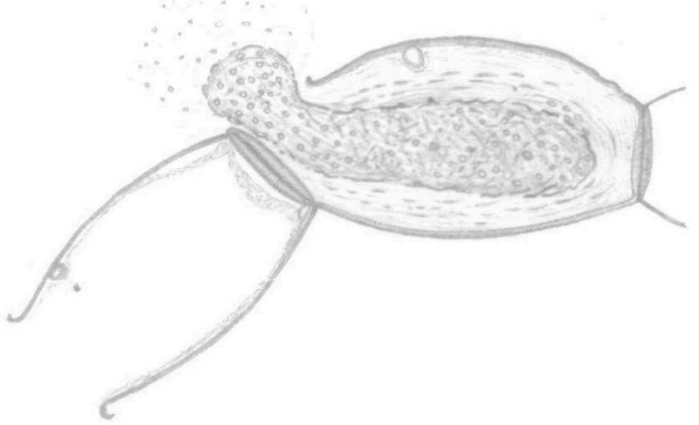



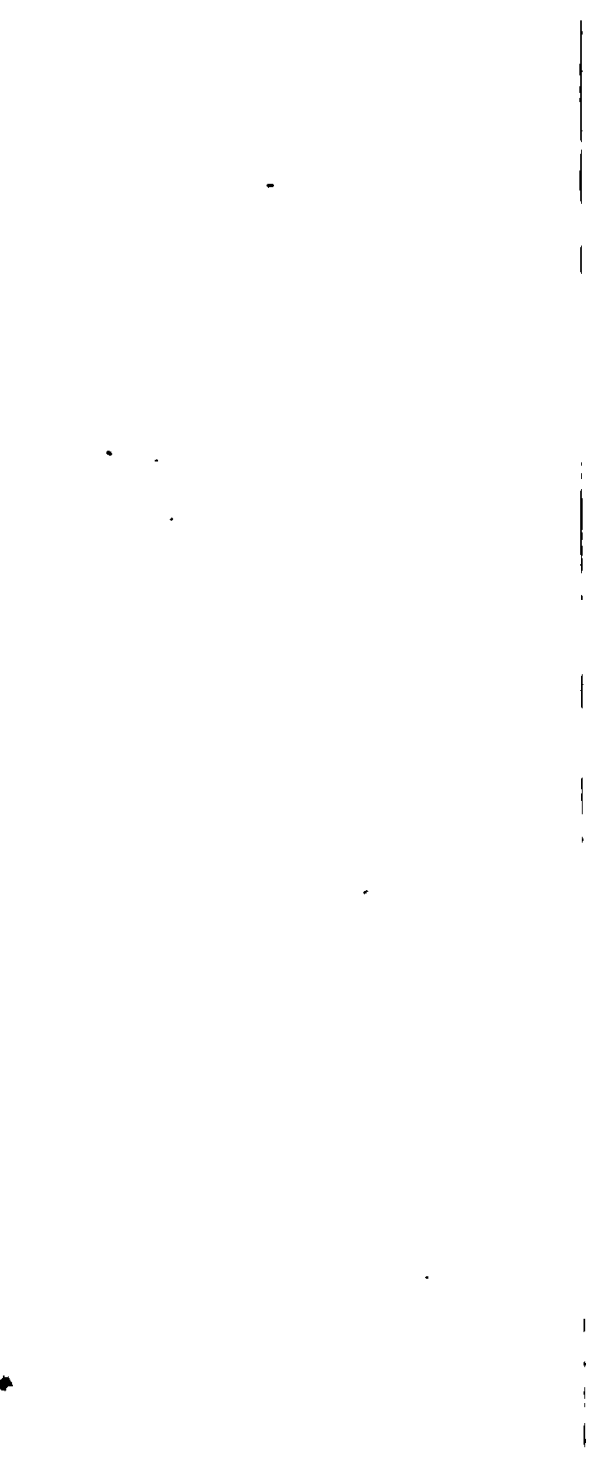